\title{
Trade integration and the destination of subsidies ${ }^{1}$
}

\author{
Nelly Exbrayat ${ }^{2}$, \\ Carl Gaigné ${ }^{3}$, \\ Stéphane Riou ${ }^{4}$
}

\section{Introduction}

European countries are increasingly subject to two constraints on the management of their public policy. The first one is the constraint on budget deficits, forcing governments to control their total expenditures. The second one is the opinion shared by most of the European countries, that competition in corporate taxes would be harmful ${ }^{5}$. Indeed, during the last twenty years, in a context of deeper trade integration and capital mobility, governments have significantly reduced their statutory corporate tax rates to promote their attractiveness (see Devereux, Griffith and Klemm, 2002) ${ }^{6}$. In a pessimistic scenario, this race to the bottom would result in a lower level of tax income and suboptimal public expenditures for immobile households (Zodrow and Mieszkowski, 1986). Under the assumption that governments are aware of these negative effects, we can anticipate that, in the future, statutory corporate tax rates will be less frequently manipulated to attract the firms. Thus, the existence of these two constraints suggests that the analysis of the allocation choice of public expenditures is particularly relevant. This is the question we raise in this article.

We wish to thank for their comments and suggestions participants at the 53rd congress of the RSAl in Toronto, at the workshop 'regional agglomeration, growth, and multi-level governance' in Ghent, at the workshop 'EU countries in fiscal competition' in Mannheim and at the 21st annual congress of the EEA in Vienna.

2 Wissenschaftszentrum Berlin für Sozialforschung (WZB) and CREUSET-CNRS, Université de Saint-Etienne. E-mail: exbrayat@wzb.eu

3 INRA, UMR1302, Rennes. E-mail : gaigne@rennes.inra.fr

4 Corresponding author. CREUSET-CNRS, Université de Saint-Etienne. E-mail: stephane.riou@univ-st-etienne.fr. adresse: Creuset, 6 rue basse des rives 42023 Saint-Etienne, cedex 02.

5 For example, the Code of Conduct for business taxation adopted by the European Union requires member states to refrain from introducing any new harmful tax measures such as an effective level of taxation which is significantly lower than the general level of taxation in the country concerned.

6 The average statutory corporate tax rate in the EU-15 members was $33.5 \%$ in 2001 and $28 \%$ in 2006 . We observe a similar tendency for the main new entrants (Hungary, Poland, Czech Republic and Slovakia): $28 \%$ in 2001 and $18 \%$ in 2006 (source: OECD tax database). 
Despite the obvious policy relevance of the subject, there is no theoretical contribution dealing with the relationship between economic integration and the destination of public expenditures. Recently, some economic geography models have provided a new analysis of public policies. By assuming imperfectly integrated economies and increasing returns to scale, this literature shows that a race to the bottom in taxation of capital is not unavoidable and the tax policies depend on the level of trade costs (see Baldwin and Krugman, 2004; Andersson and Forslid, 2003; Ludema and Wooton, 2000; Kind, Midelfart-Knarvik and Schjelderup, 2000; Ottaviano and van Ypersele, 2005) ${ }^{10}$. Nevertheless, this literature focuses on the tax policy and does not investigate what the choice of public spending would be for a given tax policy. Conversely, Keen and Marchand (1997) and Matsumoto (2000) analyze the way competition among governments distorts the pattern of public spending, but with the assumption that the economies are perfectly integrated.

Our model is based on the monopolistic competition framework with mobile firms and immobile households developed by Ottaviano and Van Ypersele (2005). Public spending has two possible allocations: a direct subsidy to households or a wage subsidy to mobile firms. Shipping the good produced in the monopolistic competitive sector is costly and we assume that the labor productivity in this sector is different among countries. Governments are benevolent, they choose the allocation of their public spending so as to maximize the welfare of the households. We neutralize tax competition by assuming exogenous capital and labor taxes in order to isolate the impact of trade integration on the choice of public spending. Nevertheless, with part of the tax base being mobile, tax revenues collected in each country are endogenous.

We show that the firms receive a lower net of tax subsidy in the highproductivity country than in the low-productivity one. Despite this less generous policy, the former country can host a larger share of firms, so that its total spending for firms can be higher than in the low-productivity country when trade costs are low enough. In this case, households are the netcontributors to the budget in both countries. The welfare analysis suggests that the second-best optimum requires an increase in the subsidy to households in both countries when the economies are weakly integrated or the productivity gap is low or the share of capital incomes redistributed outside the two economies is high.

The rest of the paper is organized as follows. The model is developed in the next section. In section 3, we investigate the spatial distribution of firms, the resulting subsidy equilibrium and the composition of public

10 See the chapter 4 in the book of Baldwin et al. (2003) for an exhaustive presentation of the contribution of the New Economic Geography literature to the analysis in the tax policies. 
produced in country $r$ from a consumer living in country $r\left(q_{r r}\right)$ and country $s$ with $s \neq r\left(q_{r s}\right)$ :

$$
q_{r r}=a-(b+c n) p_{r r}+c P_{r} \quad q_{r s}=a-(b+c n) p_{r s}+c P_{s}
$$

where $a \equiv \alpha b, b \equiv 1 /[\beta+(n-1) \delta], c \equiv \delta b /(\beta-\delta)$ and $p_{r r}$ (resp., $\left.p_{r s}\right)$ is the price of a variety produced in country $r$ for consumers of country $r$ (resp., $s$ ). Finally,

$$
P_{r}=n_{r} p_{r r}+n_{s} p_{s r} \quad P_{s}=n_{r} p_{r s}+n_{s} p_{s s}
$$

are the price indices (i.e., $n$ times the average price) of varieties in country $r$ and in country $s$, respectively, with $n_{r}$ and $n_{s}$ the number of varieties/ firms located in $r$ and $s$.

\section{$2.2 \quad$ Private sector}

The firms from the traditional sector produce a homogeneous good (the numéraire) under perfect competition and constant returns to scale. One unit of output requires one unit of labor. The T-good is traded without cost between countries so that its price as well as the wage rate in that sector are equal to unity in each country ${ }^{12}$. As workers are mobile across sectors, the wage rate is also equal to 1 in the modern sector in both countries ${ }^{13}$.

Each variety is produced by a single firm in the modern sector. We assume that the production of any variety requires a country-specific fixed amount $\phi_{r}$ of labor $l$ with

$$
\phi_{2}-\phi_{1}=\theta>0
$$

In other words, we assume that country 1 has an advantage in terms of productivity in the modern sector ${ }^{14}$. Moreover, varieties of the M-good are traded at a cost of $\tau$ units of the numéraire per unit shipped between the two countries. As firms bear these trade costs, profits of a representative firm in country $r$ are as follows:

$$
\pi_{r}=p_{r r} q_{r r} l+\left(p_{r s}-\tau\right) q_{r s} l-\phi_{r}\left(w_{r}-f_{r}\right)-t_{r}
$$

where $t_{r}$ is the unit tax in country $r$ and $f_{r}$ is the subsidy received by a firm established in country $r$ for each worker it employs ${ }^{15}$.

12 The traditional sector is perfectly competitive and firms in this sector are immobile. Hence, governments have no incentive to give them a subsidy.

13 This result holds when the sector $T$ is active in both countries, which we suppose to be checked.

14 It is necessary to normalize the marginal cost to zero in order to get analytical results when solving for the subsidy choices made by governments. This assumption is also made by Ottaviano and Van Ypersele (2005).

15 As the subsidy is linked to employment, it is not a simple tax deduction. This kind of subsidy is more and more advocated. For example, a recent report on government aid to private firms in France indicates that $43 \%$ of the publics funds allocated to firms are aimed at decreasing the labor cost (cf. Inspection Générale, 2007). 


$$
S_{r}=\frac{a^{2} n}{2 b}-a\left(n_{r} p_{r r}+n_{s} p_{s r}\right)+\frac{b+c n}{2}\left(n_{r} p_{r r}^{2}+n_{s} p_{s r}^{2}\right)-\frac{c}{2}\left(n_{r} p_{r r}+n_{s} p_{s r}\right)^{2} .
$$

As we are interested in the pattern of public expenditures, we consider taxes as given. Public expenditures and tax revenues are respectively given by $G_{r} \equiv h_{r} l+\phi_{r} f_{r} n_{r}$ and $T_{r} \equiv \rho_{r} l+t_{r} n_{r}$. Despite the exogeneity of taxes, observe that tax revenues are endogenous as the firms are mobile. Moreover, since the budget constraint requires that $G_{r}=T_{r}$, we get:

$$
\left(h_{r}-\rho_{r}\right) l=\left(t_{r}-\phi_{r} f_{r}\right) n_{r}
$$

As taxes are exogenous, we will deal with the net subsidy received by firms $\left(E_{r}\right)$ and workers $\left(H_{r}\right)$, that is:

$$
\begin{gathered}
E_{r} \equiv \phi_{r} f_{r}-t_{r} \\
H_{r} \equiv h_{r}-\rho_{r}
\end{gathered}
$$

The redistributive property of governments' public policy appears through the equality (8). Indeed, as soon as workers receive a positive net subsidy $\left(H_{r}>0\right)$, they are the net beneficiary of the public funds and as a consequence the increase in their subsidy raises the net contribution of firms to the public funds.

\section{$3 \quad$ Nash subsidies and location equilibrium}

The model consists in a sequential game involving two main players, firms and governments. In the first stage, each government simultaneously chooses its wage subsidy for firms $f_{r}$ taking as given the decision of the other government, and anticipating the impact of its decision on the private sector outcome and the location equilibrium. In stage 2, given the choices announced by governments, firms choose their place of production. All players have a perfect information and the game is solved by a sub-game perfect equilibrium involving backward induction beginning with the last stage.

\subsection{Location equilibrium}

The location of firms in sector $M$ is governed by the spatial difference in net profits evaluated at equilibrium prices. At the location equilibrium, no firm is incited to change its location. Let $\lambda \equiv n_{1} / n$ denote the share of firms located in country 1 . Formally, an interior equilibrium $\lambda^{*} \in(0 ; 1)$ occurs if and only if $\Delta\left(\lambda^{*}\right)=\pi_{r}\left(\lambda^{*}\right)-\pi_{s}\left(\lambda^{*}\right)=0$. The location forces driving this location equilibrium are the following. For given taxes and subsidies, the productivity advantage of country 1 makes it more attractive. Nevertheless, 
constraint (8) to substitute the subsidy to workers, we get the following firstorder condition:

$$
\frac{d W_{r}}{d E_{r}}=\underbrace{l \frac{\partial S_{r}}{\partial n_{r}^{*}} \frac{\partial n_{r}^{*}}{\partial E_{r}}}_{\text {surplus effect redistributive effect }} \underbrace{-n_{r}^{*}-\frac{\partial n_{r}^{*}}{\partial E_{r}} E_{r}}_{\text {profit effect }}+\underbrace{\frac{\partial \pi_{r}^{*}}{\partial E_{r}}}=0 .
$$

By attracting new firms, an increase in the level of net subsidy to firms raises the number of varieties produced on the domestic market and intensifies price competition (surplus effect). The sign of the redistributive effect depends on whether the firms are net recipients $\left(E_{r}>0\right)$ or net contributors $\left(E_{r}<0\right)$ of the public funds. The impact of an increase in $E_{r}$ on profits received by residents (profit effect) is also not obvious. If an increase in the net subsidy to firms directly improves its net profit, it also indirectly intensifies price competition and thus damages its gross profit. The net effect is finally positive. for firms:

The Nash equilibrium is described by the following levels of net subsidy

$$
E_{1}^{*}=-B \theta+C(\tau) \text { and } E_{2}^{*}=B \theta+C(\tau)
$$

where $0<B<1 / 2$ and $C(\tau)>0$ (for admissible values of $\tau$ and $\gamma$ ) are given by:

$$
\begin{gathered}
B \equiv \frac{8 b+c n(5-2 \gamma)}{2(12 b+c n(7-2 \gamma))} \\
C(\tau) \equiv \frac{2 a(b+c n)^{2} l \tau}{2(2 b+c n)^{2}}-\frac{(b+c n)\left(c^{2} n^{2}(1-\gamma / 2)+b c n(3-\gamma)+b^{2}\right) l \tau^{2}}{2(2 b+c n)^{2}}
\end{gathered}
$$

Clearly, governments are incited to pay subsidies inversely proportional to the productivity level in their country ${ }^{19}$. Thus, at the Nash equilibrium, the government of country 2 chooses the highest level of net subsidy to firms:

$$
E_{2}^{*}-E_{1}^{*}=2 B \theta>0 .
$$

Indeed, the low-productivity country sets a more generous public policy for each firm in order to limit its productivity disadvantage. Consequently, a reduction in the productivity wedge between countries decreases the international difference in net subsidies to firms $\left(\partial\left(E_{2}^{*}-E_{1}^{*}\right) / \partial \theta>0\right)$. Additionally, the more important the share of profits that remains in the economy, the more similar the levels of net subsidy to each firm are in each

19 With the expression $E_{r}^{*}$, we can define a condition on $t_{r}$ ensuring that at the Nash equilibrium, the net cost of employing a worker is still positive $\left(1-f_{r}^{*}>0\right)$. For countries 1 and 2 respectively, these conditions are given by $\phi_{1}>t_{1}-B \theta+C$ and $\phi_{2}>t_{2}+B \theta+C$. We assume they are fullfilled throughout the analysis. 
To summarize:

Proposition 1 The government of the low-productivity country sets a higher level of net subsidy for each firm than in the high-productivity country, but attracts a minority of firms.

The net subsidies received by households are given by:

$$
H_{1}^{*}=\frac{-E_{1}^{*} \lambda^{*} n}{l} \quad \text { and } \quad H_{2}^{*}=\frac{-E_{2}^{*}(1-\lambda)^{*} n}{l} .
$$

They have the opposite sign to $E_{r}^{*}$. Intuitively, the households are net beneficiary (resp. net contributors) of the public funds if the firms are net contributors (resp. net recipients). Thus, since firms located in country 2 are always net recipients of the public funds $\left(E_{2}^{*}>0\right)$, the households living in this country pay always more taxes than the amount of subsidies they receive $\left(H_{2}^{*}<0\right)$. In country 1 , the status of households with respect to the public expenditure policy is more ambiguous. It is indirectly related to the international productivity wedge on the one hand, and to the level of trade costs on the other hand. Indeed, we get $H_{1}^{*} \gtreqless 0$ if and only if:

$$
\theta \gtreqless C(\tau) / B \text {. }
$$

Moreover, we can easily check that $\theta^{\text {agglo }}>C(\tau) / B$ if and only if:

$$
\tau>\hat{\tau} \equiv \frac{2 a(b+c n)}{b^{2}+c^{2} n^{2}(9 / 4-\gamma)+b c n(5-\gamma)}<\tau_{\text {trade }}
$$

Thus, as soon as $\tau<\hat{\tau}$ (so that $\theta^{\text {agglo }}<C(\tau) / B$ ), we get $H_{1}^{*}<0$ for all interior equilibria. Stated differently, the households of the most productive country are net contributors of the public funds when economies are integrated enough. Above the threshold $\hat{\tau}$ of trade costs, both configurations can emerge depending on the size of the productivity wedge and the level of trade costs. To sum up:

Proposition 2 For all interior equilibria, the households living in the low-productivity country are always net contributors of the public funds. By contrast, the households living in the high-productivity country become net recipients of the public funds provided that trade costs and/or the productivity advantage are high enough.

\subsection{Composition of public expenditures}

We now analyze the aggregated amount of public expenditures allocated to firms and households in each country. Let $\Delta E \equiv \lambda^{*} n E_{1}^{*}-\left(1-\lambda^{*}\right)^{*} n E_{2}^{*}$ denote the international difference in aggregated net subsidies to firms. We get:

$$
\Delta E \equiv n \theta[-B+2 A C(1-2 B)]
$$


pared to those living in the other country. Thus, in the last stage of integration, trade agreements could improve the situation of households living in the low-productivity country with respect to the public policy as compared to households living in the high-productivity country.

To summarize:

Proposition 4 Trade integration first reduces and then exacerbates the international difference in the composition of public expenditures.

There are few empirical studies interested in the impact of trade integration on the composition of public expenditures. Dreher et al. (2008) show that globalization did not have a significant impact on the composition of public expenditures in OECD countries between 1971 and 2001. By contrast, Sanz and Velasquez (2004) analyze the impact of economic integration on the difference in government expenditure composition between OECD countries over the period 1970-1997. They show the existence of a convergence in the structure of government expenditures. Our analytical result suggests that the deepening of economic integration could then lead to a divergence in the evolution of the public expenditures composition.

\section{$4 \quad$ Welfare analysis}

We now analyze the public expenditures efficiency from a global point of view. Observe first that we can rewrite the aggregated welfare function as follows:

$$
W_{T}=W_{1}+W_{2}=S_{T}+H_{T}+\Pi_{T}
$$

where $S_{T} \equiv\left(S_{1}+S_{2}\right) l$ describes the total consumers' surplus, $H_{T} \equiv\left(H_{1}+H_{2}\right) l$ represents the total net subsidies to households and $\Pi_{T} \equiv \gamma\left(n_{1} \pi_{1}+n_{2} \pi_{2}\right)$ gives the total net profits received by these households.

Let us first consider the externality acting through the total consumers' surplus. So as to define its sign and its magnitude, we calculate $\partial S_{T} / \partial E_{r}$ and evaluate its value at the Nash subsidy equilibrium. We get:

$$
\left.\frac{\partial S_{T}}{\partial E_{1}}\right|_{\text {Nash }}<0 \text { and }\left.\frac{\partial S_{T}}{\partial E_{2}}\right|_{\text {Nash }}>0 .
$$

Thus, increasing the total consumers' surplus requires a coordinated policy increasing the level of net subsidy to firms in the low-productivity country and decreasing it in the other country. Stated differently, from the consumers' point of view, there is an excessive agglomeration of firms in the highproductivity country at the decentralized equilibrium. Indeed, when they decide on their levels of net subsidies, governments do not take into account the impact of their choice on the spatial distribution of firms and in fine on the consumers' surplus in the other country. 
Finally, observe that whatever the levels of trade costs and the productivity wedge, the inefficiency of the public policy in the low-productivity country is always more important than in the other country. Indeed, we get:

$$
\left.\frac{\partial W_{T}}{\partial E_{1}}\right|_{\text {Nash }}>\left.\frac{\partial W_{T}}{\partial E_{2}}\right|_{\text {Nashı }} .
$$

This result has an important implication with respect to the spatial distribution of firms. It implies that more agglomeration in the high-productivity country is required in order to improve global welfare. This result is close to the one of Ottaviano and Van Ypersele (2005) who use a similar framework. Assuming two countries of different market size, they show that in order to improve the overall welfare, a reduction in the non-cooperative tax gap is necessary as it increases the agglomeration of firms in the largest country. In other words, when a country benefits from a locational advantage, whether it comes from a lower production cost or a larger market size, it seems that the non-cooperative behavior of governments leads to a suboptimal degree of agglomeration in this country because the government of the other country tries to improve its attractiveness by being more generous with firms.

Our hypothesis of partial redistribution of profits in the economy allows us to complete the welfare analysis of Ottaviano and van Ypersele (2005). Assuming that all profits remain in the economy, they show that capital taxation is always set at an inefficiently high level in the country benefiting from a higher market size and at an inefficiently low level in the other country. Our analysis reveals that if a similar conclusion prevails for the public policy of the low-productivity country, it does not hold for the other country where the level of net subsidy to firms at the Nash equilibrium can become too high from the social welfare point of view when the share of profits repatriated outside the economy is important.

Proposition 5 At the non-cooperative equilibrium, the public expenditure policy cannot maximize global welfare: (i) in the low-productivity country, the level of net subsidy to firms is too high compared to the level of net subsidy to households; (ii) in the high-productivity country, the level of net subsidy to households is too high compared to the level of net subsidy to firms provided that a large fraction of profits remains in the economy or trade costs are low enough. 
Benassy-Quéré, A., Gobalraja, N. and A. Trannoy (2007). "Tax and public input competition", Economic Policy, vol. 22(50), pp. 385--430.

Behrens, K. and P. Picard (2005). "Tax competition, location, and horizontal foreign direct investment", CORE Discussion Paper 2005/91.

Charlton, A. (2003). "Incentive bidding for mobile investment: economic consequences and potential responses", OECD Working Paper, nº 203.

UNCTAD (1996). "Incentives and foreign direct investments", New York and Geneva: United Nations, Series A n ${ }^{\circ} 30$.

European Commission (2005). State Aid Scoreboard. COM(2005)624 final, Bruxelles.

Devereux, M.P., Griffith, R. and A. Klemm, (2002). "Corporate income tax reforms and international tax competition", Economic Policy, vol. 17(35), pp. 451-495.

Dreher, A., Sturm, J-E, and H. W. Ursprung (2008). "The impact of globalization on the composition of government expenditures: evidence from panel data". Public Choice, vol. 134(3-4), pp. 263--292.

Garrett, G. and D. Mitchell, (2001). "Globalization, government spending and taxation in the OECD", European Journal of Political Research, vol. 39(2), pp. 145-177.

Haufler A. and I. Wooton (2007). "Competition for firms in an oligopolistic industry: Do firms or countries have to pay?", Discussion paper 2007-13, University of Munich.

Inspection Générale (2007). Rapport sur les aides publiques aux entreprises, Inspection générales des Finances, des Affaires Sociales et de l'Administration, France.

Keen, M. and M. Marchand (1997). "Fiscal competition and the pattern of public spending", Journal of Public Economics, vol. 66(1), pp. 33-53.

Kind, H., K. Midelfart-Knarvik, and G. Schjelderup (2000). "Competing for capital in a lumpy world", Journal of Public Economics, vol. 78(3), pp. 253-274.

Ludema, R. and I. Wooton (2000). "Economic geography and the fiscal effects of regional integration", Journal of International Economics, vol. 52(2), pp. 331-357.

Matsumoto, M. (2000). "A note on the composition of public expenditure under capital tax competition", International Tax and Public Finance, vol. 7(6), pp. 691-697.

Ottaviano G.I.P., T. Tabuchi and J.-F. Thisse (2002). "Agglomeration and trade revisited". International Economic Review, vol. 43(2), pp. 409-436.

Ottaviano, G. and T. Van Ypersele (2005). "Market access and tax competition", Journal of International Economics, vol. 67(1), pp. 25-46.

Rodrik, D. (1997). Has globalization gone too far?, Washington D.C.: Institute for International Economics.

Rodrik, D. (1998). "Why do more open economies have bigger governments?", Journal of Political Economy, vol. 106(5), pp. 997-1032.

Sanz, I. and F. Velasquez (2004). "The evolution and convergence of the government expenditure composition in the OECD countries", Public Choice, vol. 119(1-2), pp. 61-72.

Schulze G. G. and H. W. Ursprung (1999). "Globalisation of the economy and the nation state", The World Economy, vol. 22(3), pp. 295-352.

Zodrow, G.R., and P. Mieszkowski (1986). "Pigou, Tiebout, property taxation and the underprovision of local public goods", Journal of Urban Economics, vol. 19(3), pp. 356--370. 